\title{
Microlunatus soli sp. nov., isolated from soil
}

Correspondence
Peter Kämpfer
peter.kaempfer@umwelt.uni-
giessen.de

The genus Microlunatus was proposed by Nakamura et al. (1995) and, at the time of writing, comprises four recognized species, Microlunatus phosphovorus (Nakamura et al., 1995), M. ginsengisoli (Cui et al., 2007), M. aurantiacus (Wang et al., 2008) and M. panaciterrae (An et al., 2008). These species possess LL-2,6-diaminopimelic acid (LL-Dpm) in the cell-wall peptidoglycan, MK-9 $\left(\mathrm{H}_{4}\right)$ as the predominant menaquinone and anteiso- $\mathrm{C}_{15: 0}$, iso- $\mathrm{C}_{15: 0}$ and iso- $\mathrm{C}_{16: 0}$ as major fatty acids.

Abbreviation: LL-Dpm, LL-2,6-diaminopimelic acid.

The GenBank/EMBL/DDBJ accession number for the $16 \mathrm{~S}$ rRNA gene sequence of strain CC-12602 ${ }^{\top}$ is FJ807672.

The polar lipid profile of strain CC- $12602^{\top}$ after two-dimensional TLC and detection with molybdatophosphoric acid is available as supplementary material with the online version of this paper.
A Microlunatus-like strain, CC- $12602^{\mathrm{T}}$, was isolated from a spawn used for growing the edible mushroom Agaricus brasiliensis in the laboratory and was maintained on nutrient agar (Hi-Media) after incubation at $30{ }^{\circ} \mathrm{C}$ for $48 \mathrm{~h}$. The strain was preserved at $-80{ }^{\circ} \mathrm{C}$ in nutrient broth (Hi-Media) with $20 \%$ (v/v) glycerol or by lyophilization.

Morphological properties, Gram-staining and cell morphology were observed by phase-contrast microscopy as described by Kämpfer \& Kroppenstedt (2004).

The 16S rRNA gene sequence of strain CC $-12602^{\mathrm{T}}$ was determined and analysed as described previously (Young et al., 2005). Multiple sequence alignment and analysis of the data were performed by using the software package MEGA version 4 (Tamura et al., 2007). Genetic distance calculations (distance options according to Kimura's twoparameter model) and clustering with the neighbour- 
joining method (Fig. 1) and maximum-parsimony method (not shown) were performed. Bootstrap analysis was based on 1000 replications. The $16 \mathrm{~S}$ rRNA gene sequence of strain CC- $12602^{\mathrm{T}}$ was a continuous stretch of $1475 \mathrm{bp} .16 \mathrm{~S}$ rRNA gene sequence similarity calculations after neighbour-joining analysis indicated that the closest relatives of strain CC- $12602^{\mathrm{T}}$ were M. ginsengisoli Gsoil $633^{\mathrm{T}}(96.1 \%)$, M. phosphovorus DSM $10555^{\mathrm{T}}$ (95.9\%), M. panaciterrae Gsoil $954^{\mathrm{T}}(95.8 \%)$ and $M$. aurantiacus YIM $45721^{\mathrm{T}}$ (95.5\%).

Cells cultivated in trypticase soy yeast extract medium (medium 92; http://www.dsmz.de) at $28{ }^{\circ} \mathrm{C}$ were used for isolation of the peptidoglycan after disruption of cells by shaking with glass beads and subsequent trypsin digestion, according to the method of Schleifer (1985). Amino acids and peptides in the cell-wall hydrolysates were analysed by two-dimensional ascending TLC on cellulose plates by using the solvent systems described by Schleifer (1985). Molar ratios of amino acids were determined by GC (GC 14A; Shimadzu) and GC-MS (320-MS Quadrupole GC/ MS; Varian) of $N$-heptafluorobutyryl amino acid isobutyl esters (MacKenzie, 1987; Groth et al., 1996). The hydrolysate $\left(4 \mathrm{M} \mathrm{HCl}, 100{ }^{\circ} \mathrm{C}, 16 \mathrm{~h}\right)$ of the purified peptidoglycan of strain CC- $12602^{\mathrm{T}}$ contained the amino acids LL-Dpm, alanine, glycine and glutamic acid in a molar ratio of approximately $0.8: 0.9: 2.2: 1.0$. The peptides Gly-D-Glu, D-Ala-Gly and LL-Dpm-D-Ala were detected in the partial hydrolysate $\left(4 \mathrm{M} \mathrm{HCl}, 100{ }^{\circ} \mathrm{C}, 0.75 \mathrm{~h}\right)$ of the peptidoglycan. From these data it was concluded that the peptidoglycan of strain CC- $12602^{\mathrm{T}}$ is of type $\mathrm{A} 3 \gamma^{\prime}$, based on LL-Dpm with an interpeptide bridge consisting of a single glycine residue and a second glycine residue at position 1 of the peptide subunit (Schleifer \& Kandler, 1972). Peptidoglycan type A3 $\gamma^{\prime}$ was also detected in $M$. phosphovorus, the type species of the genus (Schumann et al., 1997).

For quinone and polar lipid analyses, cells were grown for $48 \mathrm{~h}$ at $28{ }^{\circ} \mathrm{C}$ in PYE $(0.3 \%$ peptone from casein, $0.3 \%$ yeast extract, $\mathrm{pH}$ 7.2). Polyamines were extracted and analysed from PYE-grown biomass, which had been harvested at late-logarithmic growth phase, as described by Altenburger et al. (1997). Analyses of quinones and polar lipids were carried out according to Tindall (1990a, b) and Altenburger et al. (1996). HPLC conditions used for analysis of quinones and polyamines were as described by Stolz et al. (2007). The polyamine pattern was composed of the major compounds spermidine $[5.0 \mu \mathrm{mol}$ (g dry weight $\left.)^{-1}\right]$ and spermine $\left[4.3 \mu \mathrm{mol}(\mathrm{g} \text { dry weight })^{-1}\right]$. In addition, small amounts $\left.[<0.2 \mu \mathrm{mol} \text { (g dry weight })^{-1}\right]$ of putrescine and cadaverine were detected. This polyamine pattern is in accordance with that of $M$. phosphovorus and other representatives of the family Propionibacteriaceae, including members of the genera Propionibacterium, Propioniferax, Friedmanniella, Luteococcus and Tessaracoccus (Hamana, 1995; Busse \& Schumann, 1999; Kämpfer et al., 2009). The quinone system of strain CC- $12602^{\mathrm{T}}$ comprised menaquinone MK- $9\left(\mathrm{H}_{4}\right) \quad(92 \%)$ and MK- $8\left(\mathrm{H}_{4}\right)(8 \%)$. This quinone pattern is similar to those reported for recognized species of the genus Microlunatus (Nakamura et al., 1995; Cui et al., 2007; Wang et al., 2008; An et al., 2008). The polar lipid profile consisted of phosphatidylglycerol and unknown phospholipid PL3 as major components, moderate amounts of diphosphatidylglycerol, three unknown phospholipids and an unknown glycolipid, and minor amounts of another phospholipid and a polar lipid not containing a phosphate group, an amino group or a sugar moiety (Supplementary Fig. S1, available in IJSEM Online). Unlike M. aurantiacus

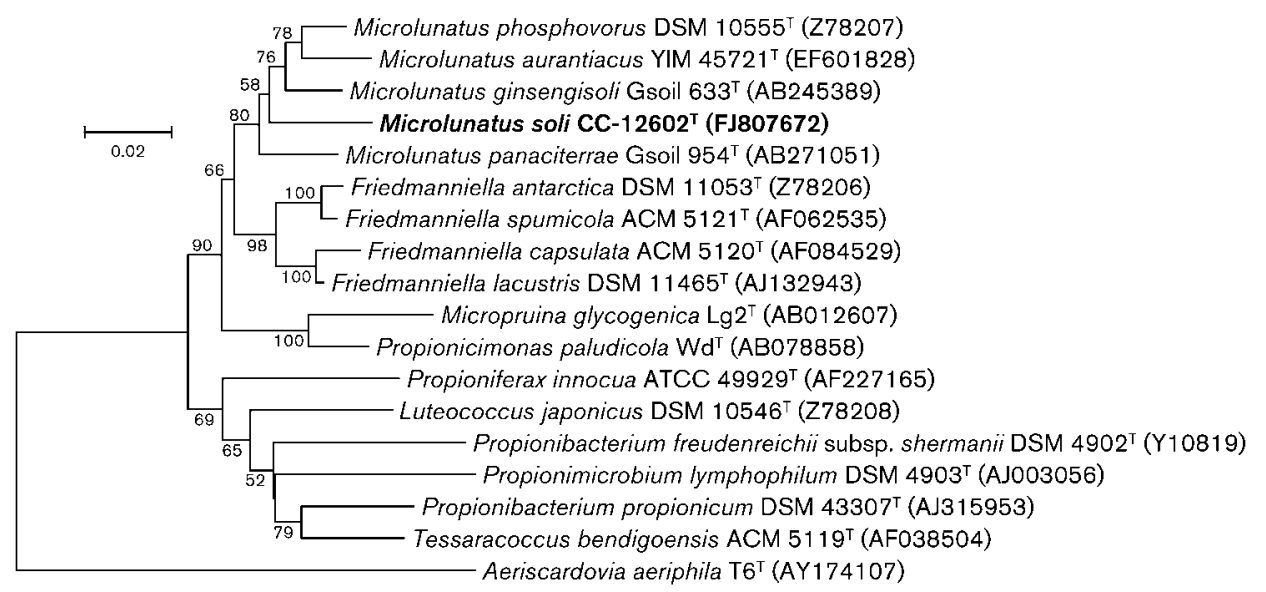

Fig. 1. Phylogenetic analysis based on $16 \mathrm{~S}$ rRNA gene sequences available from the EMBL database (accession numbers in parentheses), showing the position of strain $\mathrm{CC}-12602^{\top}$. Multiple alignment, distance calculations (distance options according to Kimura's two-parameter model) and clustering with the neighbour-joining method were performed by using the software package MEGA version 4 (Tamura et al. 2007). Bootstrap values based on 1000 replications are given as percentages at branch points. Bar, 0.02 substitutions per nucleotide position. 
(Wang et al., 2008), neither phosphatidylethanolamine nor phosphatidylinositol was detected.

Fatty acid analysis was performed according to Kämpfer \& Kroppenstedt (1996), except that strains were cultivated on

Table 1. Major fatty acids of strain CC-12602 ${ }^{\top}$ and the type strains of recognized Microlunatus species

Strains: 1, CC- $12602^{\mathrm{T}} ; 2$, M. panaciterrae Gsoil $954^{\mathrm{T}} ; 3$, M. ginsengisoli DSM $17942^{\mathrm{T}}$; 4, M. phosphovorus DSM $10555^{\mathrm{T}}$; 5, M. aurantiacus DSM $18424^{\mathrm{T}}$. Results are percentages of total fatty acids. Data are from the present study unless indicated otherwise. All strains were grown on R2A agar for 5 days at $30{ }^{\circ} \mathrm{C}$. ND, Not detected. For unsaturated fatty acids, the position of the double bond is located by counting from the methyl $(\omega)$ end of the carbon chain; cis isomers are indicated by the suffix $c$.

\begin{tabular}{|c|c|c|c|c|c|}
\hline Fatty acid & $1^{\star}$ & 2 & 3 & 4 & 5 \\
\hline \multicolumn{6}{|l|}{ Saturated } \\
\hline $\mathrm{C}_{14: 0}$ & & & & $0.5(0.5) \dagger$ & \\
\hline $\mathrm{C}_{15: 0}$ & 1.0 & $(0.8)$ & 0.9 & $0.3(1.9)$ & 1.9 \\
\hline $\mathrm{C}_{16: 0}$ & 0.6 & & 1.4 & $2.4(0.7)$ & 2.8 \\
\hline $\mathrm{C}_{17: 0}$ & & $(2.1)$ & $1.6(0.8)$ & & \\
\hline \multicolumn{6}{|l|}{ Unsaturated } \\
\hline $\mathrm{C}_{16: 1} \omega 11 c$ & 1.2 & & & & \\
\hline $\mathrm{C}_{17: 1} \omega 8 c$ & & $(8.8)$ & & & \\
\hline $\mathrm{C}_{17: 1} \omega 6 c$ & 3.0 & & & & \\
\hline $\mathrm{C}_{18: 1} \omega 7 c$ & 32.8 & & & & \\
\hline $\mathrm{C}_{20: 4} \omega 6,9,12,15 c$ & & & & & 10.0 \\
\hline \multicolumn{6}{|l|}{ Branched-chain } \\
\hline anteiso- $\mathrm{C}_{13: 0}$ & & & & $1.1(1.0)$ & 0.3 \\
\hline iso- $\mathrm{C}_{14: 0}$ & & & $4.5(8.2)$ & $5.5(8.9)$ & 4.9 \\
\hline iso- $\mathrm{C}_{15: 0}$ & 8.6 & $(17.2)$ & $21.0(13.2)$ & $22.5(17.1)$ & 4.8 \\
\hline iso- $\mathrm{C}_{15: 1} \mathrm{G}$ & & & $\mathrm{ND}(2.1)$ & & \\
\hline anteiso- $\mathrm{C}_{15: 0}$ & 18.3 & $(53.1)$ & $39.9(48.8)$ & $32.2(46.0)$ & 46.6 \\
\hline anteiso- $\mathrm{C}_{15: 1} \mathrm{~A}$ & & $(2.6)$ & $\mathrm{ND}(0.9)$ & & \\
\hline iso- $\mathrm{C}_{16: 0}$ & 15.3 & $(6.7)$ & 23.7 & $23.5(15.3)$ & 11.5 \\
\hline iso- $\mathrm{C}_{16: 1} \mathrm{H}$ & & & & $\mathrm{ND}(1.0)$ & \\
\hline anteiso- $\mathrm{C}_{16: 0}$ & & & & & \\
\hline iso- $\mathrm{C}_{17: 0}$ & 2.6 & $(2.7)$ & 1.7 & $6.8(2.2)$ & \\
\hline anteiso- $\mathrm{C}_{17: 0}$ & 8.6 & $(3.1)$ & $3.9(2.6)$ & $2.3(1.2)$ & \\
\hline \multicolumn{6}{|l|}{ Hydroxy } \\
\hline $\mathrm{C}_{14: 0} 2-\mathrm{OH}$ & 1.3 & & & & \\
\hline iso- $\mathrm{C}_{14: 0} 3-\mathrm{OH}$ & 4.3 & & & $2.7(3.9)$ & 6.4 \\
\hline Summed feature $3 \ddagger$ & & & & & 2.4 \\
\hline Summed feature $4 \ddagger$ & & $(3.1)$ & & $0.5(1.3)$ & 2.2 \\
\hline
\end{tabular}

${ }^{\star}$ It must be noted that this fatty acid profile is unusual for a member of the genus Microlunatus; however, it has been confirmed by analysis at the DSMZ (R. Pukall, personal communication). The deviations of the equivalent chain lengths for $\mathrm{C}_{16: 1} \omega 11 c$, iso- $\mathrm{C}_{14: 0} 3-\mathrm{OH}, \mathrm{C}_{14: 0}$ 2-OH, $\mathrm{C}_{17: 1} \omega 9 c$ and $\mathrm{C}_{18: 1} \omega 7 c$ are relatively high (0.004-0.008). Therefore, we cannot exclude the possibility that fatty acids other than those assigned not available in the MIDI database are present. $\dagger$ Data in parentheses are from An et al. (2008).

$¥$ Summed features are groups of two or three fatty acids that cannot be separated by GLC with the MIDI system. Summed feature 3 comprised $\mathrm{C}_{16: 1} \omega 7 c$ and/or iso- $\mathrm{C}_{15: 0} \quad 2-\mathrm{OH}$; summed feature 4 comprised iso- $\mathrm{C}_{17: 1} \mathrm{I} /$ anteiso- $\mathrm{C}_{17: 1} \mathrm{~B}$.
R2A agar for 5 days at $30{ }^{\circ} \mathrm{C}$ prior to analysis. The fatty acid profile of strain CC- $12602^{\mathrm{T}}$ was similar to those of $M$. ginsengisoli and $M$. panaciterrae, although significant differences were also observed (Table 1). Interestingly, strain CC- $12602^{\mathrm{T}}$ contained large amounts of $\mathrm{C}_{18: 1} \omega 7 c$ and small amounts of other fatty acids, not found in the four recognized Microlunatus species. Major fatty acids anteiso- $\mathrm{C}_{15: 0}$ and iso- $\mathrm{C}_{16: 0}$ typical of the genus Microlunatus were also found in strain CC- $12602^{\mathrm{T}}$.

Results of comparative physiological characterization under identical test conditions are given in Table 2 and in the species description below, with methods as described by Kämpfer et al. (1991). DNA-DNA hybridization experiments were not performed between strain CC$12602^{\mathrm{T}}$ and the type strains of recognized Microlunatus species because of the low levels of 16S rRNA gene sequence similarity $(<97 \%)$ between these strains. Differences in the fatty acid profiles and physiological test results between strain CC- $12602^{\mathrm{T}}$ and the type strains of

Table 2. Differential carbon source assimilation characteristics of strain CC- $12602^{\top}$ and the type strains of recognized Microlunatus species

Strains: 1, CC- $12602^{\mathrm{T}} ; 2$, M. aurantiacus DSM $18424^{\mathrm{T}} ; 3, M$. phosphovorus DSM $10555^{\mathrm{T}}$; 4, M. ginsengisoli DSM $17942^{\mathrm{T}}$; 5, M. panaciterrae Gsoil $954^{\mathrm{T}}$ (data from An et al., 2008). Data are from the present study unless indicated. All strains were positive for assimilation of L-arabinose $e^{\star}$, D-glucose $^{\star}$, D-mannose ${ }^{\star}$, maltose, melibiose ${ }^{\star}$, L-rhamnose, D-ribose, salicin and D-sorbitol and negative for assimilation of D-gluconate, adipate, itaconate, L-alanine, 3hydroxybenzoate, 4-hydroxybenzoate and phenylacetate. + , Positive; $(+)$, weakly positive; - , negative.

\begin{tabular}{|lccccc|}
\hline Assimilation of: & $\mathbf{1}$ & $\mathbf{2}$ & $\mathbf{3}$ & $\mathbf{4}$ & $\mathbf{5}$ \\
\hline N-Acetyl-D-glucosamine & + & + & + & + & - \\
Arbutin & + & - & + & + & - \\
Cellobiose & + & + & + & + & - \\
D-Fructose & + & + & + & + & - \\
D-Galactose & + & $(+)^{*}$ & $+^{*}$ & $+^{*}$ & - \\
Sucrose & + & + & - & + & + \\
Salicin & + & - & + & + & + \\
Trehalose & + & + & + & + & - \\
D-Xylose & + & $+^{*}$ & $+^{*}$ & $+^{*}$ & - \\
Adonitol & + & - & + & + & - \\
myo-Inositol & + & $+^{*}$ & + & + & - \\
Maltitol & + & + & + & + & - \\
D-Mannitol & + & $+^{*}$ & + & + & - \\
Acetate & + & $(+)^{*}$ & - & $(+)$ & - \\
Propionate & + & $-+^{*}$ & - & - & - \\
L-Malate & $(+)$ & $(+)^{*}$ & + & + & - \\
L-Histidine & $(+)$ & - & - & $(+)$ & - \\
L-Proline & $(+)$ & - & - & $(+)$ & - \\
L-Serine & $(+)$ & $-^{*}$ & - & - & - \\
& & & & & \\
\hline
\end{tabular}

${ }^{\star}$ In agreement with results described by An et al. (2008). 
recognized Microlunatus species (Table 2) clearly suggest that it represents a novel species of the genus Microlunatus, for which the name Microlunatus soli sp. nov. is proposed.

\section{Description of Microlunatus soli sp. nov.}

Microlunatus soli (so'li. L. neut. gen. n. soli of soil, the source of the type strain).

Cells are coccoid, about $1.0-1.5 \mu \mathrm{m}$ in diameter. Gramstain-positive, oxidase-positive and catalase-positive, showing an aerobic respiratory metabolism. Good growth occurs after 3 days of incubation on R2A agar and nutrient agar at $25-30{ }^{\circ} \mathrm{C}$. The peptidoglycan type is $\mathrm{A} 3 \gamma^{\prime}$ based on LL-Dpm. The polyamine pattern is composed of spermidine and spermine as major compounds. The quinone system comprises menaquinone MK- $9\left(\mathrm{H}_{4}\right)$ as the major component. The polar lipid profile consists of phosphatidylglycerol and unknown phospholipid PL3 as major components, moderate amounts of diphosphatidylglycerol, three unknown phospholipids and an unknown glycolipid and minor amounts of another phospholipid and a polar lipid not containing a phosphate group, an amino group or a sugar moiety. Phosphatidylethanolamine and phosphatidylinositol are not detected. Major fatty acids are anteiso$\mathrm{C}_{15: 0}$, iso- $\mathrm{C}_{16: 0}$ and $\mathrm{C}_{18: 1} \omega 7 c$ (Table 1). A small amount of $\mathrm{C}_{14: 0} 2-\mathrm{OH}$ is also found. Details of carbon source utilization (differential characteristics under identical conditions) are given in Table 2. Able to utilize numerous sugar compounds.

The type strain, CC- $12602^{\mathrm{T}}\left(=\mathrm{DSM} 21800^{\mathrm{T}}=\mathrm{CCM}\right.$ $7685^{\mathrm{T}}$ ), was isolated from a spawn used for growing the edible mushroom Agaricus brasiliensis in the laboratory.

\section{Acknowledgements}

We are grateful to Gundula Will for excellent technical assistance and to Dr Jean Euzéby for help with etymology.

\section{References}

Altenburger, P., Kämpfer, P., Makristathis, A., Lubitz, W. \& Busse, H.-J. (1996). Classification of bacteria isolated from a medieval wall painting. J Biotechnol 47, 39-52.

Altenburger, P., Kämpfer, P., Akimov, V. N., Lubitz, W. \& Busse, H.-J. (1997). Polyamine distribution in actinomycetes with group $B$ peptidoglycan and species of the genera Brevibacterium, Corynebacterium and Tsukamurella. Int J Syst Bacteriol 47, 270-277.

An, D.-S., Im, W.-T. \& Yoon, M.-H. (2008). Microlunatus panaciterrae sp. nov., a $\beta$-glucosidase-producing bacterium, isolated from soil in a ginseng field. Int J Syst Evol Microbiol 58, 2734-2738.

Busse, H.-J. \& Schumann, P. (1999). Polyamine profiles within genera of the class Actinobacteria with LL-diaminopimelic acid in the peptidoglycan. Int J Syst Bacteriol 49, 179-184.
Cui, Y. S., Im, W. T., Yin, C. R., Yang, D. C. \& Lee, S. T. (2007). Microlunatus ginsengisoli sp. nov., isolated from soil of a ginseng field. Int J Syst Evol Microbiol 57, 713-716.

Groth, I., Schumann, P., Weiss, N., Martin, K. \& Rainey, F. A. (1996). Agrococcus jenensis gen. nov., sp. nov., a new genus of actinomycetes with diaminobutyric acid in the cell wall. Int J Syst Bacteriol 46, 234239.

Hamana, K. (1995). Polyamine distribution patterns in coryneform bacteria and related gram-positive eubacteria. Annu Rep Coll Med Care Technol Gunma Univ 16, 69-77.

Kämpfer, P. \& Kroppenstedt, R. M. (1996). Numerical analysis of fatty acid patterns of coryneform bacteria and related taxa. Can J Microbiol 42, 989-1005.

Kämpfer, P. \& Kroppenstedt, R. M. (2004). Pseudonocardia benzenivorans sp. nov. Int J Syst Evol Microbiol 54, 749-751.

Kämpfer, P., Steiof, M. \& Dott, W. (1991). Microbiological characterisation of a fuel-oil contaminated site including numerical identification of heterotrophic water and soil bacteria. Microb Ecol 21, 227-251.

Kämpfer, P., Lodders, N., Warfolomeow, I. \& Busse, H.-J. (2009). Tessaracoccus lubricantis sp. nov., isolated from a metalworking fluid. Int J Syst Evol Microbiol 59, 1545-1549.

MacKenzie, S. L. (1987). Gas chromatographic analysis of amino acids as the $N$-heptafluorobutyryl isobutyl esters. J Assoc Off Anal Chem 70, 151-160.

Nakamura, K., Hiraishi, A., Yoshimi, Y., Kawaharasaki, M., Masuda, K. \& Kamagata, Y. (1995). Microlunatus phosphovorus gen. nov., sp. nov., a new gram-positive polyphosphate-accumulating bacterium isolated from activated sludge. Int $J$ Syst Bacteriol 45, 17-22.

Schleifer, K. H. (1985). Analysis of the chemical composition and primary structure of murein. Methods Microbiol 18, 123-156.

Schleifer, K. H. \& Kandler, O. (1972). Peptidoglycan types of bacterial cell walls and their taxonomic implications. Bacteriol Rev 36, 407-477.

Schumann, P., Prauser, H., Rainey, F. A., Stackebrandt, E. \& Hirsch, P. (1997). Friedmanniella antarctica gen. nov., sp. nov., an LL-diaminopimelic acid-containing actinomycete from Antarctic sandstone. Int $J$ Syst Bacteriol 47, 278-283.

Stolz, A., Busse, H.-J. \& Kämpfer, P. (2007). Pseudomonas knackmussii sp. nov. Int J Syst Evol Microbiol 57, 572-576.

Tamura, K., Dudley, J., Nei, M. \& Kumar, S. (2007). MEGA4: molecular evolutionary genetics analysis (MEGA) software version 4.0. Mol Biol Evol 24, 1596-1599.

Tindall, B. J. (1990a). A comparative study of the lipid composition of Halobacterium saccharovorum from various sources. Syst Appl Microbiol 13, 128-130.

Tindall, B. J. (1990b). Lipid composition of Halobacterium lacusprofundi. FEMS Microbiol Lett 66, 199-202.

Wang, Y.-X., Cai, M., Zhi, X.-Y., Zhang, Y.-Q., Tang, S.-K., Yu, L.-H., Cui, X.-L. \& Li, W.-J. (2008). Microlunatus aurantiacus sp. nov., a novel actinobacterium isolated from a rhizosphere soil sample. Int J Syst Evol Microbiol 58, 1873-1877.

Young, C.-C., Kämpfer, P., Shen, F.-T., Lai, W.-A. \& Arun, A. B. (2005). Chryseobacterium formosense sp. nov., isolated from the rhizosphere of Lactuca sativa L. (garden lettuce). Int J Syst Evol Microbiol 55, 423426. 